Regards sur l'économie allemande

Bulletin économique du CIRAC

$111 \mid 2013$

Varia

\title{
Famille : les rôles traditionnels ont la vie dure
}

\section{Solène Hazouard}

\section{OpenEdition}

Journals

Édition électronique

URL : http://journals.openedition.org/rea/4632

DOI : 10.4000/rea.4632

ISSN : 1965-0787

Éditeur

CIRAC

\section{Édition imprimée}

Date de publication : 1 décembre 2013

Pagination : 36

ISSN : 1156-8992

\section{Référence électronique}

Solène Hazouard, «Famille : les rôles traditionnels ont la vie dure », Regards sur l'économie allemande

[En ligne], 111 | décembre 2013, mis en ligne le 18 décembre 2013, consulté le 15 septembre 2020. URL : http://journals.openedition.org/rea/4632

Ce document a été généré automatiquement le 15 septembre 2020.

(c) CIRAC 


\title{
Famille : les rôles traditionnels ont la vie dure
}

\author{
Solène Hazouard
}

Pour la neuvième année consécutive, l'Institut für Demoskopie Allensbach (IfD) a mené une étude sur les familles pour le compte de la holding familiale allemande Vorwerk. Dans l'édition 2013, la Vorwerk Familienstudie témoigne de la persistance, dans les esprits, du modèle traditionnel de répartition des tâches au sein du couple.

\section{La carrière des hommes est privilégiée}

2 A cet égard en effet, les mentalités n'ont guère évolué ces vingt dernières années : bien que la part des femmes occupant un emploi ait entre-temps grimpé de $55 \%$ à $68 \%$, sur les quelque 1500 Allemands interrogés dans le cadre de l'enquête, seulement $44 \%$ envisagent que l'homme mette sa carrière entre parenthèses pour permettre à sa femme de travailler. Ce taux a baissé chez les hommes, avec $47 \%$ en 1993 contre $40 \%$ en 2013. Mais plus surprenant encore, il a chuté de 6 points chez les femmes, se réduisant ainsi à $48 \%$ ! De plus, parmi les hommes sondés, l'idée de travailler à mitemps pour favoriser l'activité professionnelle de leur femme a reculé de 3 points ces vingt dernières années. Néanmoins, les hommes se disent aujourd'hui davantage disposés à s'occuper des enfants le soir pour permettre à leur femme de sortir : les trois quarts d'entre eux l'envisagent volontiers.

\section{Les femmes doivent concilier vie familiale et vie professionnelle}

3 Autre constance : les tâches domestiques et familiales incombent toujours en grande partie aux femmes, près de $80 \%$ des mères affirmant en assumer la charge principale. Pas étonnant dès lors à ce que les mères actives - la plupart du temps à temps partiel aient le sentiment de manquer de temps. 
4 Or, pour $74 \%$ des Allemands, la conciliation entre vie familiale et vie professionnelle demeure le principal objectif en matière de politique familiale. C'est ce que révèle pour sa part la sixième vague de l'enquête Monitor Familienleben, réalisée par l'IfD pour le compte du ministère fédéral de la Famille, des Personnes âgées, de la Femme et de la Jeunesse (BMFSFJ). Cet enjeu, combiné à celui de l'égalité des chances dès le plus jeune âge, plaide pour le développement des crèches. Ainsi, $73 \%$ des quelque 1800 personnes sondées se prononcent en faveur du droit - en vigueur depuis le $1^{\text {er }}$ août 2013 - à une place d'accueil pour tout enfant âgé d'au moins un an (sur ce sujet, voir le bilan économique du gouvernement Merkel II dans ce numéro). Les parents d'enfants en âge scolaire plébiscitent pour leur part une prise en charge à temps plein, qu'il s'agisse d'activités l'après-midi ou d'un enseignement réparti sur l'ensemble de la journée. (SH)

INDEX

Mots-clés : famille, politique familiale, société, femme, groupe social, marché du travail, emploi 